UDC 539.3

\title{
SOME ASPECTS OF CONSIDERATION OF INITIAL IMPERFECTIONS IN THE CALCULATIONS OF STABILITY OF THIN-WALLED ELEMENTS OF OPEN PROFILE
}

\author{
I.O. Okhten \\ O.O. Lukianchenko, \\ Doctor of Technical Science \\ Kyiv National University of Construction and Architecture \\ 31, Povitroflotsky ave., Kyiv, Ukraine
}

DOI: $10.32347 / 2410-2547.2021 .106 .122-128$

\begin{abstract}
Performed analysis of the initial geometric imperfections influence on the stability of the open C-shaped bars. Imperfections are given in different formulations: the general stability loss of an ideal bar, of wavy bulging of walls and shelves, of deplanation of a bar. Researches made in with different values of the imperfection amplitude and eccentricity of applied efforts. All tasks are performed in linear and nonlinear staging. The conclusion is made regarding the influence of initial imperfections form on the critical force in nonlinear calculations. It was found that the most affected are imperfections, which are given in the form of total loss of stability. It was revealed the influence of the imperfection amplitude on the magnitude of the critical force for such imperfections. The influence of imperfections amplitude given in the form of wavy bulging walls and in the form of deplanations is not affected on the value of the critical force.
\end{abstract}

Keywords: thin-walled bars, geometry imperfection, eccentricity, finite element method, stability, critical force.

Introduction. The appling of thin-walled steel constructions in building allows to solve a wide range of problems. For these structures even founded, a separate class - light steel thin-walled structures (LSTWS). This is due to their advantages:

- Reduction of metal consumption in structures (according to 10-15\%)

- Light weight of each element allows to make installation without construction cranes

- Manufacturing technology allows the use of $\mathrm{CNC}$ machines and ensure high manufacturing accuracy

- Manufacturing technology allows you to galvanizing elements, which significantly increases their corrosion resistance.

- Due to the high accuracy of manufacturing, it is possible to perform installation according to the principle of "designer" without the use of welding, drilling and without "wet" processes.

The most convenient in the manufacture are thin-walled cold-formed openprofile bars. Such profiles are often used as compressed elements of building structures (columns, farms, etc.). Under compression, or off-center compression, the depletion of the bearing capacity of such structures usually goes through the stability loss. The stability loss of thin-walled elements takes place in such forms: bending, torsion, bending and torsional. However, due to

Okhten I.O., Lukianchenko O.O. 
the decrease in the thickness of the elements in such profiles, the features of the work begin to manifest themselves, which are not described by the theory of thin-walled bars V.Z. Vlasov [1]. Unlike classical theory, thin-walled elements have deformation of the profile, in the form of wave-like deformation of individual plates (shelves, walls, bends).

These features of the work are already widely researched. The article [2] describes the theory of coherent protrusion of thin-walled bars, which simultaneously takes into account different forms of stability loss: general (for which the contour of the profile is not deformed) and local (for which line of contact individual plates forming bars remain stationary). Such interactions are nonlinear, because in linear theory all their own forms, namely general and local, are independent (orthogonal).

Problem statement and its solution. However, thin-walled cold-formed profiles with an open cross-section have another feature - susceptibility to local deformations that occur during the manufacture, transportation, installation or operation of elements. Such defects can significantly affect the stability loss of the element, and, accordingly, lead to structural violations. Such defects can significantly affect the stability loss of the element and, accordingly, lead to structural damage.

Given the above, the following tasks are set:

- Investigate the impact of imperfections that are set in the overall, local and torque forms of sustainability loss.

- Investigate the impact of imperfections amplitude.

- Investigate the effect of load eccentricity.

All tasks are performed in linear and nonlinear staging.

To model imperfections, has been developed a program which for the formation of new coordinates of the nodes of the "deformed" model, the components of a vector similar to the form of stability loss are added to the corresponding coordinates of the middle surface of the bar. In this way, you can set initial imperfections in the forms of stability loss of the bar with different amplitude.

As the object of research, a common C-shaped profile $200 \times 57 \times 22,5 \times 2000$ was chosen. Steel «СтЗкп, ДСТУ 2651:2005 [6]» with the following mechanical characteristics is laid as the material: $E=2.1 \cdot 10^{11} \mathrm{~Pa}, \mu=0.3$. The imperfection amplitude is taken in proportion to the thickness of the bar wall $t$ : $\delta / t=[0.25 ; 0.5 ; 1.0 ; 1.5]$.

Results of the calculation and analysis of solutions. Calculations of ideal bars in linear setting showed that the stability loss can occur in one of four forms: a total stability loss - Fig. 1(a), wave-like bulging of the walls Fig. 1(b), bar deplanation - Fig. 1(b) and stability loss at the ends of the bar Fig. 1(d). Similar forms are obtained in laboratory testing [3]. These calculations (see Fig. 2) showed that the range of critical forces is very "wide" (the difference between them is less than 5\%). Therefore, it is necessary to take into account not only the first form, but also a number of subsequent ones when modeling imperfections in the form of forms of stability loss. 


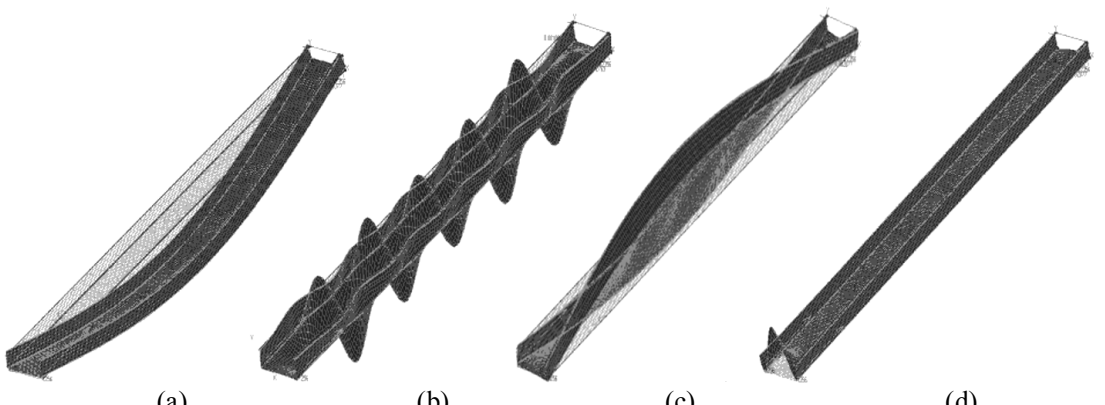

(a)

(b)

(c)

(d)

Fig. 1. Forms of stability loss of bars at linear calculation: total (a), wave-like bulging of the walls (b), bar deplanation (b), stability loss at the ends of the bar (d)

In the test tasks without eccentricity, the first form of stability loss for the ideal bar occurs in the form of a wave-like bulging of the wall and shelves (Fig. 3). This form is transformed by the above method into initial defects with different amplitudes for nonlinear calculations.

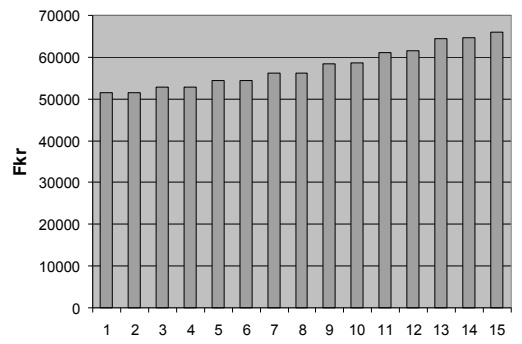

Fig. 2. The range of critical forces

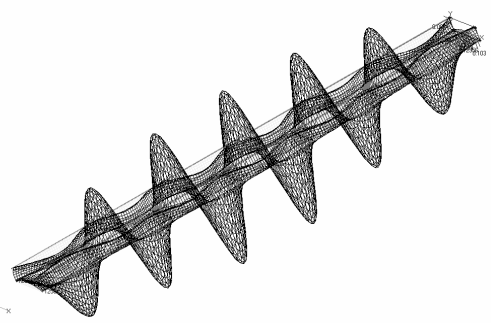

Fig. 3. the first form of stability loss for the ideal bar

In fig. 4 shows the results of such calculations. Here on the axis of abscission the amplitude of imperfections is deposited, and on the axis of ordinary - the value of critical force. The graph is divided into two parts: linear and nonlinear calculations.

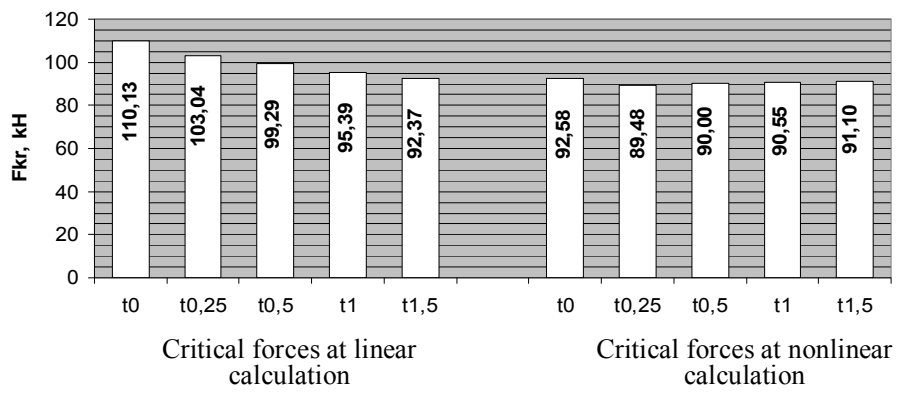

Fig. 4. The results of calculations of the centrally compressed bar 
In test problems with a load applied with eccentricity $e=10 \mathrm{~mm}$ and $e=$ $20 \mathrm{~mm}$, the ideal bar has stability loss in the form of bar deplanation (first form), means twisting relative to its own axis (Fig. 9). In Fig. 5 and Fig. 6 are given the results of such calculations in the form of graphs.

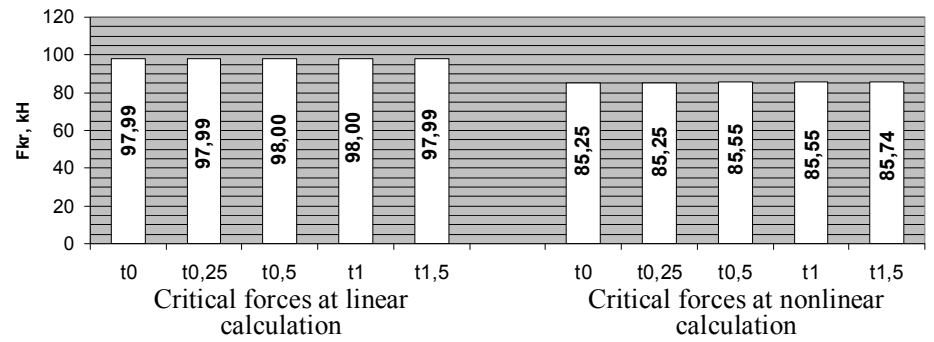

Fig. 5. The results of calculations of the eccentrically compressed bar ( $e=10 \mathrm{Mm})$

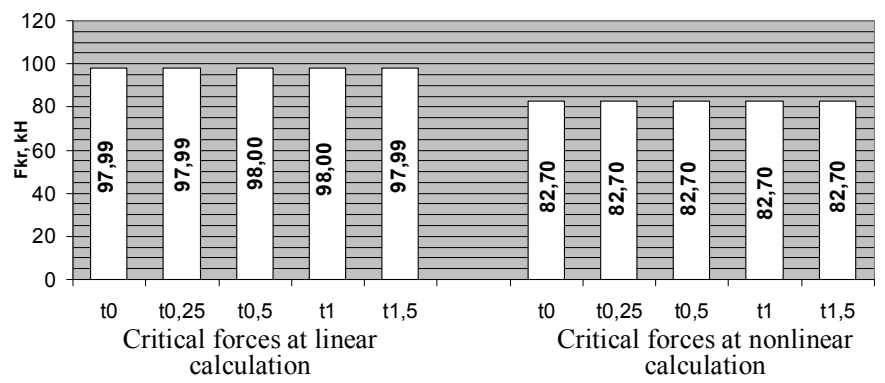

Fig. 6. The results of calculations of the eccentrically compressed bar $(e=20 \mathrm{Mm})$

Additionally, was researched the influence of imperfections specified in the form of a general stability loss was investigated, which, for that the bar was fifteen (the first was in the form of wave-like bulging of the walls - see Fig. 7(a) and Fig. 7(b).

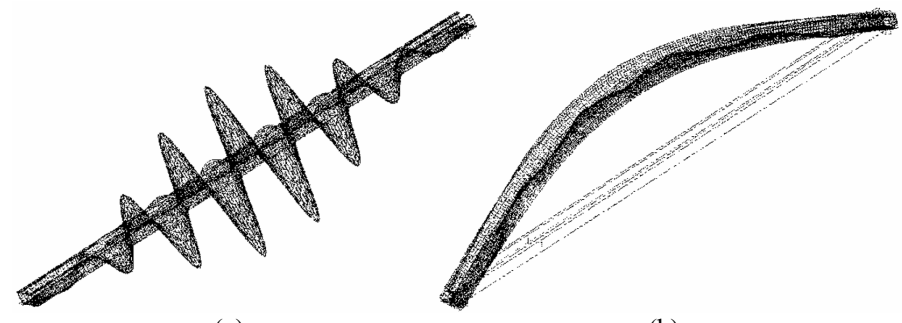

(a)

(b)

Fig. 7. Form of stability loss: (a) first, (б) fifteens

In Fig. 9 are given the results of such calculations. Here we see a dependence of the bar's stability on the amplitude of initial imperfections, which was not seen in previous test tasks - see Fig. 4, 5, 6. 


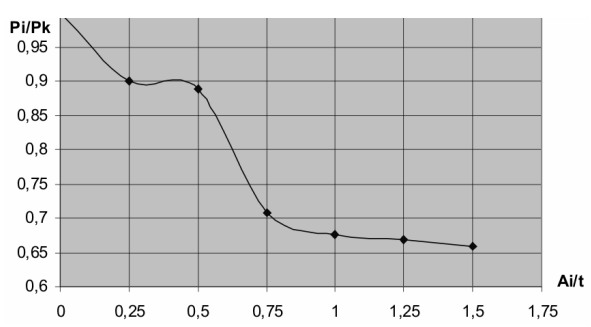

Fig. 8. The dependence of the critical force on the initial value imperfections in the general (15th) form of stability loss

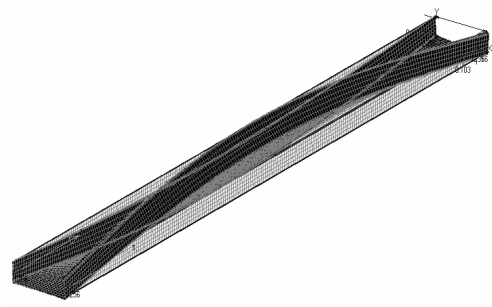

Fig. 9. The first form of stability loss of an ideal bar at eccentric compression: $e=10 \mathrm{~mm}$ та $e=20 \mathrm{~mm}$

\section{Conclusions}

1. Modeling imperfections in the form of general, local and torsional forms of stability loss differently affect the stability of the bars.

2. Imperfections in the form of general stability loss significantly reduce the critical load value compared to other simulated imperfections.

3. An increase in the amplitude of defects in the form of a total stability loss leads to a decrease in the magnitude of the critical force (with increasing amplitude, the critical force decreases).

\section{REFERENCES}

1. Vlasov V.Z. Tonkostennyie uprugie sterzhni (Thin-walled elastic bars). - Moskow: Fizmatgiz, 1959. - $574 \mathrm{p}$.

2. Raksha S.V. Poterya kogerentnoy ustoychivosti i optimizatsiya vesa tonkostennyih sterzhney otkryitogo profilya (Coherent stability loss and weight optimization of thin-walled bars of an open profile). Dissertation for the degree of Doctor of Technical Sciences. Dnipro - 2003.

3. Okhten I.O., Gotsulyak E.A., Lukianchenko O.O. Doslidzhennia stiikosti tonkostinnykh elementiv vidkrytoho profiliu z urakhuvanniam pochatkovykh nedoskonalostei (Research of thin-walled elements firmness of an open profile taking into account initial imperfections) // Strength of Materials and Theory of Structures: The scientific and technical collected articles. Issue. 82. - K.: KNUBA, 2008. - P. 131-136.

4. Okhten I.O., Gotsulyak E.A., Lukianchenko O.O. Doslidzhennia sumisnoho vplyvu pochatkovykh nedoskonalostei i ekstsentrysytetu na stiikist sterzhniv vidkrytoho profiliu (Research of compatible influence of initial imperfections and eccentricity on firmness of an open profile cores) // Strength of Materials and Theory of Structures: The scientific and technical collected articles. - Issue. 83. - K.: KNUBA, 2009. - P. 126-132.

5. Volmir A.S. Ustoichyvost deformyruemikh system (Stability of deformable systems). Moskow: Nauka, 1967. - 984 p.

6. Timoshenko S.P. Ustoichyvost sterzhnei, plastin i obolochek (Stability of bars, plates and shells). - Moskow: Nauka, 1971. $-807 \mathrm{p}$.

7. Shimkovich D.G. Raschet konstruktsiy v MSC/NASTRAN for Windows (Calculation of structures in MSC / NASTRAN for Windows). - M.: DMK Press, 2001.

8. Lukianchenko O.O., Kostina O.V. The finite Element Method in Problems of the Thin Shells Theory. - LAP LAMBERT Academic Publishing, 2019. 
Охтень І.О., Лук'янченко О.О.

\section{ДЕЯКІ АСПЕКТИ ВРАХУВАННЯ ПОЧАТКОВИХ НЕДОСКОНАЛОСТЕЙ У РОЗРАХУНКАХ СТІЙКОСТІ ТОНКОСТІННИХ ЕЛЕМЕНТІВ ВІДКРИТОГО ПРОФІЛЮ}

У роботі досліджено вплив початкових недосконалостей форми на стійкість стержнів відкритого С-подібного профілю. Тестові задачі вирішувалися у програмному комплексі MSC Nastran, що базується на методі кінечних елементів. Геометричні недосконалості стержнів задані у формах: загальної втрати стійкості ідеального стержня, хвилеподібного випучування стінок та полиць, депланації стержня. Для моделювання недосконалостей використана програма, в якій для формування нових координат вузлів «деформованої» моделі стержня компоненти вектора подібного до форми втрати стійкості додаються до відповідних координат серединної поверхні стержня. Таки чином можна моделювати початкові недосконалості по формам втрати стійкості стержня 3 різними значеннями амплітуди та імпортувати отриману кінечно-елементну модель у розрахунковий комплекс. Описані дослідження стійкості стержнів з різними амплітудами недосконалостей форми та різними значеннями ексцентриситету прикладення сил виконані в лінійній і нелінійній постановках. На основі тестових задач зроблено висновок щодо впливу форми та амплітуди початкових недосконалостей на критичну силу. Визначено, що найбільший вплив мають недосконалості у формі загальної втрати стійкості. Для таких недосконалостей виявлено вплив амплітуди недосконалостей на величину критичної сили. Вплив амплітуди недосконалостей, що задані у формі хвилеподібного випучування стінок та у формі депланації, на величину критичної сили не значний.

Ключові слова: тонкостінні стержні, геометричні недосконалості, ексцентриситет, метод скінченних елементів, стійкість, критична сила.

Okhten I.O., Lukianchenko O.O.

\section{SOME ASPECTS OF CONSIDERATION OF INITIAL IMPERFECTIONS IN THE CALCULATIONS OF STABILITY OF THIN-WALLED ELEMENTS OF OPEN PROFILE}

Performed analysis of the initial geometric imperfections influence on the stability of the open C-shaped bars. Test tasks were solved in MSC Nastran, which is based on the finite element method. Imperfections are given in different formulations: the general stability loss of an ideal bar, of wavy bulging of walls and shelves, of deplanation of a bar. To model imperfections, has been developed a program which for the formation of new coordinates of the nodes of the "deformed" model, the components of a vector similar to the form of stability loss are added to the corresponding coordinates of the middle surface of the bar. In this way, you can set initial imperfections in the forms of stability loss of the bar with different amplitude. Researches made with different values of the imperfection amplitude and eccentricity of applied efforts. All tasks are performed in linear and nonlinear staging. The conclusion is made regarding the influence of initial imperfections form and imperfection amplitude on the critical force in nonlinear calculations. It was found that the most affected are imperfections, which are given in the form of total loss of stability. It was revealed the influence of the imperfection amplitude on the magnitude of the critical force for such imperfections. The influence of imperfections amplitude given in the form of wavy bulging walls and in the form of deplanations is not affected on the value of the critical force.

Keywords: thin-walled bars, geometry imperfection, eccentricity, finite element method, stability, critical force. 


\section{УДК 539.3}

Охтень I.О., Лук'янченко О.О. Деякі аспекти врахування початкових недосконалостей у розрахунках стійкості тонкостінних елементів відкритого профілю // Опір матеріалі $\mathrm{i}$ теорія споруд: наук.-тех. збірн. - К: КНУБА, 2021 - Вип. 106. - С. 122-128.

У роботі досліджено вплив початкових недосконалостей форми на стійкість стержнів відкритого C-подібного профілю. Геометричні недосконалості стержнів задані у формах: загальної втрати стійкості ідеального стержня, хвилеподібного випучування стінок та полиць, депланації стержня. Дослідження стійкості стержнів з різними амплітудами недосконалостей форми та ексиентриситету прикладення сил виконані в лінійній і нелінійній постановках.

Іл. 9. Бібліогр. 8 назв.

\section{UDC 539.3}

Okhten I.O., Lukianchenko O.O. Some aspects of consideration of initial imperfections in the calculations of stability of thin-walled elements of open profile // Strength of Materials and Theory of Structures: Scientificand-technical collected articles. - K.: KNUBA, 2021. - Issue 106. - P. 122-128.

Performed analysis of the initial geometric imperfections influence on the stability of the open $C$-shaped bars. Imperfections are given in different formulations: the general stability loss of an ideal bar, of wavy bulging of walls and shelves, of deplanation of a bar. Researches made in with different values of the imperfection amplitude and eccentricity of applied efforts. All tasks are performed in linear and nonlinear staging.

Fig. 9. Ref. 8.

\section{УДК 539.3}

Охтень И.А., Лукьянченко О.А. Некоторые аспекты учета начальных несовершенств в расчетах устойчивости тонкостенных элементов открытого профиля // Сопротивление материалов и теория сооружений: науч.-тех. сборн. - К.: КНУСА, 2021. - Вып. 106. - С. 122-128.

В роботе проведены исследования влияния начальных несовериенств формы на устойчивость стержней открытого С-образного профиля. Геометрические несовершенства заданы в разных формах: общей потере устойчивости идеального стержня, волнообразного выпучивания стенок и полок, депланации стержня. Исследования устойчивости стержней выполнены с разными значениями амплитуды несовершенств и эксиентриситета приложения усилий в линейной и нелинейной постановках.

Ил. 9. Библиогр. 8 назв.

Автор (науковий ступінь, вчене звання, посада): директор ТОВ «Проектна компанія «ФУТУРІСТА», ОХТЕНЬ Іван Олександрович.

Адреса робоча: 01001 Україна, м. Київ, провулок Рильський 10/3 Охтеню Івану Олександровичу.

Робочий тел.: +38(067) 785-01-01.

Мобільний тел.: +38(097) 640-82-82.

E-mail: iokhten@gmail.com

ORCID ID: http://orcid.org/0000-0003-1794-6030

Автор (науковий ступінь, вчене звання, посада): доктор технічних наук, старший науковий співробітник НДІ будівельної механіки КНУБА, ЛУК'ЯНЧЕНКО Ольга Олексіївна.

Адреса робоча: 03680 Україна, м. Київ, Повітрофлотський проспект 31, Київський національний університет будівництва і архітектури, ЛУК’ ЯНЧЕНКО Ользі Олексіївні.

Робочий тел.: +38(044) 241-54-20.

Мобільний тел.: +38(095) 727-18-25.

E-mail: lukianchenko.oo@knuba.edu.ua, lukianch0907@meta.ua

ORCID ID: http://orcid.org/0000-0003-1794-6030 